\title{
Effect of platelet-activating factor on the release of PGF- $2 \alpha$ and PGE-2 by separated cells of human endometrium
}

\author{
S. K. Smith and R. W. Kelly \\ Medical Research Council Reproductive Biology Unit, Centre for Reproductive Biology, \\ 37 Chalmers Street, Edinburgh EH3 9EW, U.K.
}

\begin{abstract}
Summary. Synthetic platelet-activating factor (PAF-acether, 1-0-alkyl-2-acetylsn-glycero-3-phosphocholine) caused a dose-dependent increase in the synthesis of prostaglandin (PG) E-2 by an enriched glandular, but not stromal, fraction of human endometrium removed in the secretory phase of the menstrual cycle. PAFacether did not alter the synthesis of PGF- $2 \alpha$ by this fraction and consequently there was a significant reduction in the ratio of the amounts of PGF-2 $\alpha /$ PGE- 2 released by the cells into the culture medium. The preimplantation human embryo secretes PAF, and these findings may have relevance to the local maternal recognition of pregnancy.
\end{abstract}

Keywords: endometrium; platelet activating factor; prostaglandin; implantation; human

\section{Introduction}

The events surrounding implantation in women are poorly understood yet failure of implantation is a frequent cause of natural embryonic loss (Short, 1979) and contributes to a high failure rate of in-vitro fertilization (Edwards \& Steptoe, 1983; Yovich et al., 1984). In mice, the initial maternal response to pregnancy is a mild thrombocytopenia (O'Neill, 1985a) caused by the release of an embryo-derived factor, with chemical, biochemical and physiological properties similar to those of platelet-activating factor (PAF-acether, 1-0-2-acetyl-sn-glycero-3-phosphocholine) (O'Neill, 1985b; Snyder, 1985). The preimplantation embryo of the human is also able to synthesize a factor similar to PAF-acether (O'Neill et al., 1985) which may be the cause of the mild thrombocytopenia found in some conception cycles in women. Of particular interest is the observation that the ability of embryos to secrete this factor might influence the chances of subsequent pregnancy after embryo transfer (O'Neill \& Saunders, 1984). The means by which PAF exerts this effect are obscure.

In non-primate species, the site of implantation is characterized by an area of increased vascular permeability around the blastocyst, readily demonstrated by the extravasation of Evans or Protamine blue dyes (Psychoyos \& Martel, 1985). There is evidence to suggest that PGs may be involved in the initiation in these changes. Levels of 6-keto-PGF-1 $\alpha$, PGF-2 $\alpha$ and PGE-2 are higher in the sites of increased vascular permeability (Kennedy \& Zamecnik, 1978; Sharma, 1979). Indomethacin, an inhibitor of PG synthesis, alters the local increase in endometrial vascular permeability in the rabbit (Hoffman et al., 1978), hamster (Evans \& Kennedy, 1978), mouse (Lundkvist \& Nilsson, 1980) and rat (Phillips \& Poyser, 1981) and blocks or delays implantation in the mouse (Saksena et al., 1976), rabbit (El-Banna, 1980) and pig (Kraeling et al., 1985). A possible role of embryo-derived PAF could be the stimulation of PG synthesis by endometrium to induce changes which will facilitate successful implantation. The aim of this study was to determine whether PAF-acether could stimulate human glandular and stromal cells to synthesize and release PGs. 


\section{Materials and Methods}

Endometrium was obtained from the uterine cavity of 9 women undergoing dilation and curettage or abdominal hysterectomy performed for non-malignant conditions. Informed consent was obtained and the study was passed by the local ethical committee. All of the women had regular menstrual cycles and tissue was removed between Days 18 and 22 of the chronological menstrual cycle (Day 1 = first day of menstruation).

Tissue collection. The technique used to prepare the enriched fractions of glandular and stromal cells was based on that of Satyaswaroop et al. (1979). Endometrium removed at operation was placed in sterile, filtered Hank's Balanced Salt Solution (HBSS) (Flow Laboratories, Irvine, U.K.) which contained gentamycin $(50 \mu \mathrm{g} / \mathrm{ml})$ and amphotericin-B $(5 \mu \mathrm{g} / \mathrm{ml})$ (Fungizone: Flow Laboratories) and taken to the laboratory. Under aseptic conditions, strips of endometrium were placed in $\mathrm{Ca}^{2+}$ - and $\mathrm{Mg}^{2+}$-free HBSS containing collagenase $(1 \mathrm{mg} / \mathrm{ml})$, DNase $(0 \cdot 2 \mathrm{mg} / \mathrm{ml})(\mathrm{both}$ purchased from Sigma Chemical Co. Ltd, Poole, Dorset, U.K.), Hepes buffer $(20 \mathrm{~mm})$, gentamycin $(50 \mu \mathrm{g} / \mathrm{ml})$, and amphotericin-B $(5 \mu \mathrm{g} / \mathrm{ml})$. The tissue was cut into approximately $1 \mathrm{~mm}$ pieces and placed in a shaking-water bath at $37^{\circ} \mathrm{C}$ for 60-120 min. The preparation was examined under phase-contrast microscopy at 15 min intervals to determine the degree of separation of the glands from the surrounding stromal cells.

The glandular structures were isolated from the single cell stromal fraction by passage through a $35 \mu \mathrm{m}$ nylon mesh (Henry Simon, Stockport, U.K.). The glands were retained on the mesh and the enriched glandular preparation was obtained by back-flushing the mesh with HBSS. It is clear that surface epithelial cells will have passed into the stromal preparation and that some sheets of inadequately dispersed stromal cells would be retained on the mesh. These preparations are not pure but represent enriched fractions of glandular and stromal cells, and the terms glands and stroma will be used in the text to refer to these preparations.

Cell culture. The glandular and stromal preparations were centrifuged at $1500 \mathrm{~g}$ for 15 min, washed and resuspended in a mixture of Dulbecco's Modified Eagles Medium and Ham's F12 nutrient medium (1:1 v/v) (Flow Laboratories) which contained fetal calf serum substitute, Ultroser (2\%) (LKB Laboratories), minimum essential medium, non-essential amino-acids (1\%) (Sigma), L-glutamine (10 mm) (Flow Laboratories), Hepes buffer (20 mm), insulin $(10 \mu \mathrm{g} / \mathrm{ml})$, gentamycin $(50 \mu \mathrm{g} / \mathrm{ml})$, and amphotericin-B $(5 \mu \mathrm{g} / \mathrm{ml})$.

The suspensions were placed over $1.5 \mathrm{ml}$ of a $60 \%$ Percoll gradient and centrifuged at $1500 \mathrm{~g}$ for $15 \mathrm{~min}$ to remove red blood cells from the preparations. The endometrial glands or stromal cells were retained as a band above the Percoll and were pipetted and resuspended in the above medium. Aliquants $(500 \mu \mathrm{l})$ were placed in microtitre plates (Nunclon, Nunc; Flow Laboratories).

Platelet-activating factor (Sigma) was dissolved in ethanol and glandular and stromal preparations were incubated with $0,1,10$ or $100 \mathrm{ng} \mathrm{PAF} / \mathrm{ml}$. All incubations were performed in duplicate. The glandular and stromal cells were incubated for $24 \mathrm{~h}$ in a humidified atmosphere at $37^{\circ} \mathrm{C}$ in $95 \% \mathrm{O}_{2}$ and $5 \% \mathrm{CO}_{2}$. Cell viability was assessed at the end of the incubation period by the Trypan blue dye exclusion test and was assessed as greater than $80 \%$ in all cases.

After $24 \mathrm{~h}$, media were removed and centrifuged at $1500 \mathrm{~g}$ for $15 \mathrm{~min}$ and $250 \mu \mathrm{l}$ samples were mixed with an equal volume of methyloximating solution (methoxyamine hydrochloride $0 \cdot 12 \mathrm{M}$-sodium acetate buffer, $\mathrm{pH} 5 \cdot 6-5 \cdot 8$ ). The retained cells were resuspended in $500 \mu$ l phosphate-buffered saline (Dulbecco's formula without $\mathrm{Ca}^{2+}$ and $\mathrm{Mg}^{2+}$ ) (Flow Laboratories), containing trypsin $(0.1 \%)$ and EDTA $(0.2 \%, \mathrm{w} / \mathrm{v})$. These aliquants were returned to their original microtitre wells and left for $15 \mathrm{~min}$ to permit separation of the attached cells. The cells in suspension were removed, centrifuged at $1500 \mathrm{~g}$ for $15 \mathrm{~min}$ and resuspended in HBSS for subsequent estimation of protein content, using the tecnique of Lowry et al. (1951).

Measurement of PGs. Standard PGF-2 $\alpha$ and PGE-2 were purchased from Sigma and 15-keto-13, 14-dihydroPGF-2 $\alpha$ (PFFM) and PGE-2 (PGEM) were kindly provided by Dr J. Pike (The Upjohn Co. Ltd, Kalamazoo, Michigan, U.S.A.). Tritiated PGs were bought from Amersham International PLC, Bucks, U.K. All PGs were measured by radioimmunoassay using specific antisera raised in rabbits to the methyloximated PG. The crossreactivities of these antisera have been described previously (Kelly et al., 1986). The sensitivity of the assays, defined as the amount of PG distinguishable from zero with a $95 \%$ confidence limit was $2 \mathrm{pg} /$ well for both assays. The precision of the measurements within the assays was $10 \cdot 5 \%$ for PGF- $2 \alpha, 12 \cdot 3 \%$ for PGE-2, $13 \cdot 5 \%$ for PGFM, $4 \cdot 6 \%$ for PGEM and between assays, was $13.9 \%$ for PGF-2 $\alpha, 13 \cdot 3 \%$ for PGE-2, 13.3\% for PGFM and 15\% for PGEM.

Statistical analysis. As there were wide between-patient differences in PG release, the effect of PAF is expressed graphically as percentage change of the amount of $P G$ released by the control incubation (percentage change $=$ amount of PG released with PAF $\times 100 /$ amount of PG released without PAF). Analysis of the effect of incremental doses of PAF on PG release was performed on the original data by analysis of variance with repeated measures using one within-subject variable when assessing the effect of dose on each tissue or two within-subject variables when assessing the comparative effects of dose on different tissue types. Since within-cell errors of raw PG results tended to be proportional to cell means, the data were logarithmically transformed before analysis. Values in the text and tables are the antilogs of the mean and the mean \pm standard error of the mean (s.e.m.).

\section{Results}

As shown in Table 1, the glandular preparations synthesized more PGF-2 $\alpha$ (df $=1, F=5.905$, $P<0.05)$ and PGE-2 (df $=1, \mathrm{~F}=20.638, P<0.005)$ than did the stromal fractions. In the 
control incubations of the glandular cells, PGF- $2 \alpha$ release was greater than $\mathrm{PGE}-2$ release $(\mathrm{df}=1$, $\mathrm{F}=9.011, P<0.01)$.

The release of $P G$ into the medium probably reflects de-novo synthesis of PGs, as in two separate experiments indomethacin $(100 \mathrm{~nm})$, an inhibitor of PG synthesis, reduced the levels of PGF- $2 \alpha$ in the medium of glandular preparations from 1039.00 and $629.20 \mathrm{ng} / \mathrm{mg}$ protein $/ 24 \mathrm{~h}$ to 147.90 and $120.62 \mathrm{ng} / \mathrm{mg}$ protein $/ 24 \mathrm{~h}$, and in stromal fractions from the same tissue from 108.16 and $22.10 \mathrm{ng} / \mathrm{mg}$ protein $/ 24 \mathrm{~h}$ to 5.63 and $9.26 \mathrm{ng} / \mathrm{mg}$ protein $/ 24 \mathrm{~h}$. The levels of PGFM and PGEM in the media were considerably lower than the levels of PGF-2 $\alpha$ and PGE-2.

Platelet-activating factor significantly increased the release of PGE-2 by the enriched glandular fraction when analysed within patient ( $\mathrm{df}=3, \mathrm{~F}=4.141, P<0.025)$, but had no effect on the synthesis of PGE-2 by the stromal cells (Fig. 1a). Levels of PGF-2 $\alpha$ declined with incremental doses of PAF but this effect was not statistically significant when comparing the effect of dose or dose and tissue type on PG levels (Fig. 1b). However, at a dose of $100 \mathrm{ng} \mathrm{PAF} / \mathrm{ml}$, the mean amounts of PGF-2 $\alpha$ in culture medium had declined from $119 \cdot 71$ (s.e.m. $79 \cdot 1-179 \cdot 81$ ) to $80 \cdot 80$ (s.e.m. $56 \cdot 32$ $115.90) \mathrm{ng} / \mathrm{mg}$ protein $/ 24 \mathrm{~h}$, whereas the levels of PGE-2 had risen from $30 \cdot 56$ (s.e.m. 22.03-42.40) to 54.00 (s.e.m. $37 \cdot 50-77 \cdot 25$ ) $\mathrm{ng} / \mathrm{mg}$ protein $/ 24 \mathrm{~h}$. Consequently, the ratio of the amounts of PGF- $2 \alpha$ to PGE-2 released by the glandular fractions into the culture medium were reduced by PAF-acether (df $=3, \mathrm{~F}=3 \cdot 290, P<0.05$ ) (Fig. 2).

There was no change in the relative amounts of PGF-2 $\alpha$ and PGE-2 synthesized by the stromal fractions, and there was no change in the amounts of PGFM or PGEM released by glands or stroma in the presence of incremental doses of PAF.

\section{Discussion}

Synthetic platelet-activating factor increased the synthesis of PGE-2 by glandular epithelial cells of mid-secretory endometrium and promoted a slight decline in the release of PGF- $2 \alpha$ such that the ratio of PGF- $2 \alpha$ to PGE-2 released into the medium was reduced. The stromal cells of the endometrium released smaller amounts of both PGF- $2 \alpha$ and PGE-2 into the medium than did the glandular cells and this release was not affected by PAF-acether. These findings indicate that PAFacether is capable of altering the relative amounts of PG released by glandular cells, at least in the in-vitro system studied here.

PAF has been shown to stimulate the release of eicosanoids from several haemopoetic cells including platelets (Shaw et al., 1981) and neutrophils (Roubin et al., 1983), and to stimulate PGE2 synthesis from rat mesangial cells (Schlondorff et al., 1984) and human amnion (Billah et al., 1985). In this study, haemopoietic cells would be expected to be present in the predominantly singlecelled, stromal preparations and are not likely to have been the main source of PG release in the glandular fraction. In rabbit platelets (Lee et al., 1983) and neutrophils (O'Flaherty et al., 1982) this effect is mediated by an influx of $\mathrm{Ca}^{2+}$ into the cell. Prostaglandins are synthesized from nonesterified arachidonic acid which is released directly from phosphatidylethanolamine by the action of phospholipase $\mathrm{A}_{2}$ and indirectly after cleavage from phosphatidylinositol by phospholipase $\mathrm{C}$, by the activity of mono- and diacylglycerol lipases (Challis, 1985). Phospholipases $A_{2}$ and $C$ are stimulated by $\mathrm{Ca}^{2+}$. Previous studies have shown that addition of excess arachidonic acid to human endometrial and decidual cells results in a disproportionate increase in PGE-2 synthesis compared to PGF-2 $\alpha$ (Smith \& Kelly, 1987). The reason for this difference in PG synthesis is obscure but could reflect non-enzymic conversion of endoperoxides to PGE-2 or saturation of PGF- $2 \alpha$ reductase activity. This could explain the findings in this study if PAF caused an increase in intracellular, non-esterified arachidonic acid which resulted in a relatively larger increase in PGE-2 than PGF$2 \alpha$. In the ovary, PGE-2 is converted to PGF-2 $\alpha$ by 9-ketoreductase (Watson et al., 1979), and reduced activity of this enzyme would result in increased amounts of PGE-2, but this enzyme has not been identified in human epithelial cells of endometrium. 
Table 1. Mean ( \pm s.e.m.) amounts (antilogs of logarithmically transformed data) of $P G$ released into the culture medium over $24 \mathrm{~h}$ in culture $(n=9)$ by enriched fractions of glandular and stromal preparations of human secretory endometrium

\begin{tabular}{|c|c|c|c|c|}
\hline & \multicolumn{4}{|c|}{ PG conc. (ng/mg protein $/ 24 \mathrm{~h}$ ) } \\
\hline & PGF-2 $\alpha$ & PGFM & PGE-2 & PGEM \\
\hline \multicolumn{5}{|l|}{ Glands } \\
\hline Mean & $119 \cdot 21$ & $10 \cdot 86$ & $30 \cdot 56$ & $3 \cdot 83$ \\
\hline s.e.m & $79 \cdot 1-179 \cdot 81$ & $6.44-18.34$ & $22 \cdot 03-42 \cdot 40$ & $2 \cdot 82-5 \cdot 19$ \\
\hline \multicolumn{5}{|l|}{ Stroma } \\
\hline Mean & $38 \cdot 01$ & $8 \cdot 18$ & $10 \cdot 86$ & $2 \cdot 64$ \\
\hline s.e.m & $23 \cdot 55-61 \cdot 36$ & $4 \cdot 19-15 \cdot 28$ & $6.93-17.03$ & $1.40-4.09$ \\
\hline
\end{tabular}

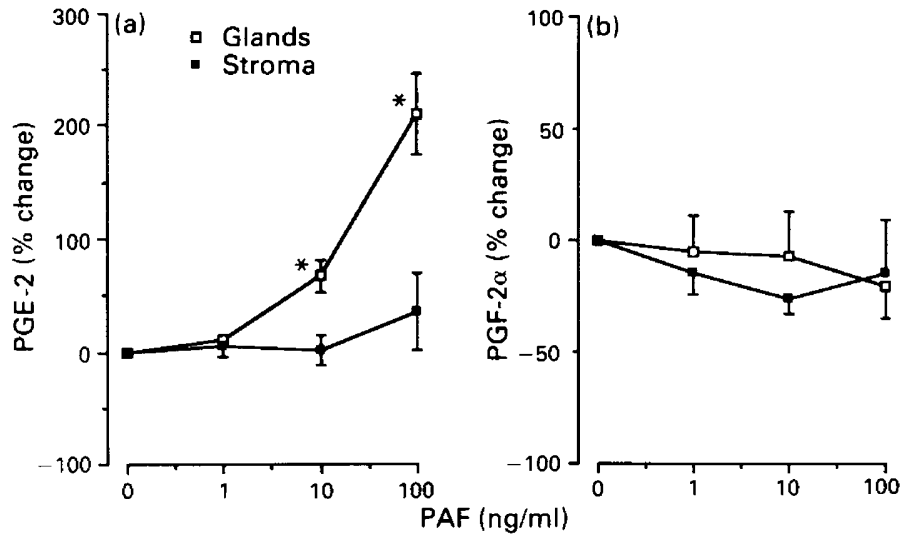

Fig. 1. Mean ( \pm s.e.m.) change in the concentrations of (a) PGE-2 and (b) PGF-2 $\alpha$ in culture media after incubation with synthetic PAF for $24 \mathrm{~h}$ of enriched preparations of glandular $(\square)$ and stromal $(\boldsymbol{D})$ cells obtained from human secretory endometrium. ${ }^{*} P<0.025$.

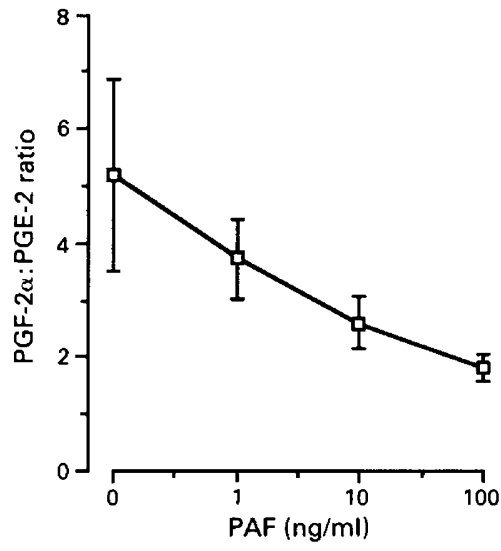

Fig. 2. Mean ( \pm s.e.m.) change in the ratio of the amounts of PGF-2 $\alpha$ and PGE-2 released into culture medium over $24 \mathrm{~h}$ after incubation with synthetic platelet activating factor. There was a significant decline in the PGF-2 $\alpha /$ PGE-2 ratio $(\mathrm{df}=3, \mathrm{~F}=3.290, P<0.05)$. 
Because of the action of PAF, there is a relative increase in the amounts of PGE-2 released by glandular epithelial cells of the endometrium compared to PGF-2 $\alpha$. This might have important consequences for implantation. In laboratory species there is evidence that PGE-2 induces changes in local vascular permeability and stromal oedema which precede implantation (Kennedy, 1983). In the rat (Kennedy et al., 1983), pig (Kennedy et al., 1986) and human (Hofman et al., 1985) the endometrium contains specific receptors for PGE-2. Furthermore, in the rat (Kennedy et al., 1983) these receptors are only situated on the stromal cells. Decidualization in laboratory species differs from that in women as it arises as a consequence of the action of a stimulus (e.g. the presence of the embryo in the uterine cavity) on a primed endometrium, whereas in women decidual change does not require a stimulus. However, these decidual changes in women occur around Day 23 of the menstrual cycle after implantation has begun (Hearn, 1986) and the effect of changes in the relative amounts of PGF- $2 \alpha$ and PGE-2 released by glandular epithelium on local vascular permeability of human endometrium is unknown.

Nevertheless, human embryos do release PAF (O'Neill et al., 1985) and the ability of these embryos to implant successfully after embryo transfer is reflected in their ability to release PAF (O'Neill \& Saunders, 1984). At present the first clear signal received by the mother of the presence of the embryo is the release of chorionic gonadotrophic hormone, synthesized by the trophoblast and detectable in maternal blood around 9 days after ovulation (Ross, 1979).

The findings from this study suggest the possibility of an alternative, earlier signal arising from the preimplantation embryo which could initiate changes in the endometrium required for implantation. Further studies are required to investigate the action of PAF on the glandular epithelial cells of the endometrium, and to determine the possible relevance of this action to successful implantation.

We thank the Consultants and staff of Ward 36 and Theatre 36, Royal Infirmary, Edinburgh, for their help with this study, and Ms E. Nairn and Ms P. Holland for excellent technical assistance.

\section{References}

Billah, M.M., DiRenzo, G.C., Ban, C., Truong, C.T., Hoffman, D.R., Anceschi, M.M., Bleasdale, J.E. \& Johnston, J.M. (1985) Platelet-activating factor metabolism in human amnion and the responses of this tissue to extracellular platelet-activating factor. Prostaglandins 30, 841-851.

Challis, J.R.G. (1985) Factors responsible for parturition. In The Role of Prostaglandins in Labour, pp. 514. Roy. Soc. Med. Serv., London.

Edwards, R.G. \& Steptoe, P.C. (1983) Current status of in-vitro fertilisation and implantation of human embryos. Lancet ii, 1265-1269.

El-Banna, A.A. (1980) The degenerative effect on rabbit implantation sites by indomethacin. I. Timing of indomethacin action, possible effect of uterine proteins and the effect of replacement doses of $\mathrm{PGF}_{2 \mathrm{a}}$. Prostaglandins 20, 587-599.

Evans, C.A. \& Kennedy, T.G. (1978) The importance of prostaglandin synthesis for the initiation of blastocyst implantation in the hamster. J. Reprod. Fert. 54, 255-261.

Hearn, J.P. (1986) The embryo-maternal dialogue early pregnancy in primates. J. Reprod. Fert. 76, 809-819

Hoffman, L.H., DePietro, D.L. \& McKenna, T.J. (1978) Effects of indomethacin on uterine capillary permeablity and blastocyst development in rabbits. Prostaglandins 15, 823-828.
Hofman, G.E., Rao, C.V., De Leon, F.D., Toledo, A.A. \& Sanfilippo, J.S. (1985) Human endometrial prostaglandin E2 binding sites and their profiles during the menstrual cycle and in pathological states. Am. $J$. Obstet. Gynecol. 151, 369-375.

Kelly, R.W., Deam, S., Cameron, R.F. \& Seamark, R.F. (1986) Measurement by radioimmunoassay of prostaglandins as their methyl oximes. Prost. Leuk. Med. 24, 1-14.

Kennedy, T.G. (1983) Embryonic signals and the initiation of blastocyst implantation. Aust. J. biol. Sci 36, 531-543.

Kennedy, T.G. \& Zamecnik, J. (1978) The concentration of 6-keto prostaglandin Fla is markedly elevated at the site of blastocyst implantation in the rat. Prostaglandins 61, 599-606.

Kennedy, T.G., Martel, D. \& Psychoyos, A. (1983) Endometrial prostaglandin E2 binding during the estrous cycle and its hormonal control in ovariectomized rat. Biol. Reprod. 29, 565 571.

Kennedy, T.G., Keys, J.L. \& King, G.J. (1986) Endometrial prostaglandin E2 binding sites in the pig: characterization and changes during the estrous cycle and early pregnancy. Biol. Reprod. 35, 624-632.

Kraeling, R.R., Rampacek, G.B. \& Fiorello, N.A. (1985) Inhibition of pregnancy with indomethacin in mature 
gilts and prepubertal gilts induced to ovulate. Biol. Reprod. 32, 105-110.

Lee, T.C., Malone, B. \& Snyder, F. (1983) Stimulation of calcium uptake by 1-alkyl-2-acetyl-sn-glycero-3phospho-choline (Platelet-activating-factor) in rabbit platelets. Archs Biochem. Biophys. 223, 33-39.

Lowry, O.H., Rosebrough, N.J., Farr, A.L. \& Randall, R.J. (1951) Protein measurement with the Folin phenol reagent. J. biol. Chem. 193, 265-275.

Lundkvist, O. \& Nilsson, B.O. (1980) Ultrastructural changes of the trophoblast-epithelial complex in mice subjected to implantation blocking treatment with indomethacin. Biol. Reprod. 22, 719-726.

O'Flaherty, J.T., Swendson, C.L., Lees, C.J.S. \& McCall, C.E. (1982) Role of extracellular calcium in neutrophil degranulation. Responses to 1-0-alkyl-2acetyl-sn-glycero-3-phospho-choline. Am. J. Path. 105, 107-113.

O'Neill, C. (1985a) Thrombocytopenia is an initial maternal response to fertilization in mice. $J$. Reprod. Fert. 73, 559-566.

O'Neill, C. (1985b) Partial characterization of the embryo-derived platelet-activating factor in mice. $J$. Reprod. Fert. 75, 375-380.

O'Neill, C. \& Saunders, D.M. (1984) Assessment of embryo quality. Lancet iv, 1035.

O'Neill, C., Pike, I., Porter, N., Gidley-Baird, A.A., Sinosich, M.J. \& Saunders, D.M. (1985) Maternal recognition of pregnancy prior to implantation: methods for monitoring embryonic viability in-vitro and in-vivo. Ann. N.Y. Acad. Sci. 442, 429-439.

Phillips, C.A. \& Poyser, N.L. (1981) Studies on the involvement of prostaglandins in implantation in the rat. J. Reprod. Fert. 62, 73-81.

Psychoyos, A. \& Martel, D. (1985) Embryo-endometrial interactions at implantation. In Implantation of the Human Embryo, pp. 197-219. Eds R. G. Edwards, J. M. Purdy \& P. C. Steptoe. Academic Press, London.

Ross, G.T. (1979) Human chorionic gonadotrophin and maternal recognition of pregnancy. In Maternal Recognition of Pregnancy (Ciba Fdn Symp. No. 64), pp. 191-208. Excerpta Medica, Amsterdam.

Roubin, R., Tence, M., Mencia-Huerta, J.M., Arnoux, B., Ninio, E. \& Benveniste, J. (1983) A chemically defined monokine: macrophage-derived plateletactivating factor (PAF-Acether). In Lymphokines,
Ch. 8, pp. 249-276. Ed. E. Pike. Academic Press, New York.

Saksena, S.K., Lau, I.F. \& Chang, M.C. (1976) Relationship between oestrogen, prostaglandin $F_{2 \alpha}$ and histamine in delayed implantation in the mouse. Acta endocr., Copenh. 42, 225-232.

Satyaswaroop, P.G., Bressler, R., de la Pena, M.M. \& Gurpide, E. (1979) Isolation and culture of human endometrial glands. J. clin. Endocr. Metab. 48, 639-641.

Schlondorf,, D., Satriano, J.A., Hagege, J., Perez, J. \& Band, L. (1984) Effect of platelet-activating factor and serum treated zymosan on prostaglandin E2 synthesis, arachidonic acid release, and contraction of cultured rat mesangial cells. J. clin. Invest. 73, 1227-1231.

Sharma, S.C. (1979) Temporal changes in PGE, PGF2 $\alpha$, oestradiol $17 \beta$ and progesterone in uterine venous plasma and endometrium of rabbits during early pregnancy. INSERM Colloq. 91, 243-264.

Shaw, J.O., Klusick, S.J. \& Hanahan, D.J. (1981) Activation of rabbit platelet phospholipase and thromboxane synthesis by 1-0-hexadecyl/octadecyl2-acetyl-sn-glyceryl-3-phosphocholine (Platelet Activating Factor). Biochim. Biophys. Acta 663, 222-229.

Short, R.V. (1979) When a conception fails to become a pregnancy. In Maternal Recognition of Pregnancy (Ciba Fdn Symp. No. 64), pp. 377-395. Excerpta Medica, Amsterdam.

Smith, S.K. \& Kelly, R.W. (1987) The effect of the antiprogestins, RU 486 and ZK 98734 on the synthesis and metabolism of $\mathrm{PGF}_{2} \alpha$ and $\mathrm{PGE}_{2}$ in separated cells from early human decidua. J. clin. Endocr. Metab. G, 527-537.

Snyder, F. (1985) Chemical and biochemical aspects of platelet activating factor: a novel class of acetylated ether-linked choline-phospho-lipids. Med. Res. Rev. 5, 107-140.

Watson, J., Shepherd, T.S. \& Dodson, K.S. (1979) Prostaglandin E-2-9-keto-reductase in ovarian tissues. $J$. Reprod. Fert. 57, 489496.

Yovich, J.L., Stanger, J.D., Yovich, J.M. \& Tuvick, A.I. (1984) Quality of embryos from in-vitro fertilisation. Lancet i, 457.

Received 21 May 1987 